\title{
Metode Index Card Match Meningkatkan Prestasi Belajar PKn
}

\author{
Hari Subagyo ${ }^{(1)}$ \\ ${ }^{1}$ Guru Sekolah Dasar Negeri 1 Kedungsigit \\ Email: ${ }^{1}$ harisub@gmail.com \\ DOI: https://doi.org/10.28926/riset_konseptual.v2i2.36
}

\begin{abstract}
ABSTRAK
Observasi awal pada pembelajaran PKn kelas IV SDN 1 Kedungsigit terdapat permasalahan, guru menyampaikan materi dengan metode ceramah, siswa bersikap pasif dalam proses pembelajaran, pembelajaran terkesan teoritis, dan guru belum mampu memanfaatkan model pembelajaran secara optimal. Penelitian Tindakan Kelas (PTK) dilaksanakan dalam 2 siklus yang tiap siklusnya terdiri dari 4 tahap yaitu perencanaan, pelaksanaan, pengamatan, dan refleksi. Instrumen yang digunakan adalah lembar tes individu, lembar kerja kelompok, pedoman observasi, catatan lapangan, dan dokumentasi, sedangkan analisis data yang digunakan adalah analisis deskriptif kualitatif. Penelitian menunjukkan bahwa metode index card match pada pembelajaran PKn telah berhasil meningkatkan Prestasi Belajar siswa. Ini dibuktikan dengan nilai rata-rata pada keadaan awal sebanyak sebesar 56,00 meningkat menjadi 66,00 pada siklus I dan pada akhir siklus II meningkat menjadi 74,00 dengan tingkat ketuntasan belajar dari 1 siswa atau $10 \%$ menjadi 6 siswa atau $60 \%$ dan meningkat menjadi 10 siswa atau $100 \%$ pada siklus kedua. Berdasarkan hasil penelitian, disimpulkan bahwa metode index card match dalam pembelajaran PKn tema globalisasi dapat dilaksanakan dengan baik dan dapat meningkatkan prestasi belajar siswa.
\end{abstract}

Kata kunci: globalisasi, hasil, belajar, index card match

\section{PENDAHULUAN}

Keberhasilan proses belajar mengajar tidak terlepas dari cara pendidik mengajar dan siswa belajar sebab baik tidaknya hasil proses belajar mengajar dapat dilihat dan dirasakan oleh pendidik dan siswa sendiri. Secara terminologi metode adalah alat untuk mencapai tujuan pengajaran pendidikan. Dalam lingkungan dunia pendidikan, metode itu banyak macamnya seperti metode ceramah, metode diskusi, metode demonstrasi dan sebagainya. Para guru hendaknya mempunyai kemampuan memilih model pembelajaran yang tepat untuk setiap pokok bahasan. Selain itu pembelajaran PKn juga dapat menggunakan media pengajaran yang bermacam-macam di antaranya menampilkan gambar, film, peta dan lainnya untuk menambah pemahaman terhadap data visual. Masih rendahnya hasil belajar siswa terhadap mata pelajaran PKn disebabkan masih dominannya skill menghafal daripada skill memproses. Berdasarkan hasil observasi yang dilakukan terhadap siswa, ada sebagian siswa yang menganggap mata pelajaran PKn tidak begitu penting dikarenakan tidak masuk pada mata pelajaran yang akan diujikan pada Ujian Nasional (UN). Kondisi pembelajaran seperti inilah yang mengakibatkan siswa kurang efektif. Guru dituntut untuk pandai menciptakan suasana metode mengajar yang menyenangkan bagi siswa sehingga siswa kembali berminat mengikuti kegiatan belajar. Dari siswa kelas IV yang berjumlah 10 anak, hanya 1 siswa (10\%) yang mencapai kategori tuntas. Artinya sebagian besar siswa belum mencapai tingkat penguasaan materi $70 \%$ ke atas atau mendapat nilai sama dengan KKM sebesar 70 .

Metode index card match dapat meningkatkan hasil belajar dan mendidik siswa untuk belajar mengemukakan pikiran atau pendapat, melatih siswa untuk berdiskusi serta dapat mengembangkan rasa toleransi terhadap pendapat yang berbeda. Metode index card match diaplikasikan dalam proses belajar mengajar agar siswa mampu berfikir kritis, mengekspresikan pendapatnya secara bebas, dapat 
menyumbangkan buah pikirannya untuk memecahkan masalah bersama dan mengambil satu atau beberapa alternatif jawaban untuk memecahkan masalah berdasarkan pertimbangan yang seksama, dan pembelajaran yang sudah dirancang dapat membantu siswa memahami teori secara mendalam melalui pengalaman belajar. Hal ini sejalan dengan pendapat Slavin (1994) dalam Baharuddin (2008: 116117) yang menyatakan bahwa Dalam proses belajar dan pembelajaran siswa harus terlibat aktif dan siswa menjadi pusat kegiatan belajar dan pembelajaran di kelas. Guru dapat memfasilitasi proses ini dengan menggunakan cara-cara yang membuat sebuah informasi menjadi bermakna dan relevan bagi siswa, untuk itu, guru harus memberi kesempatan kepada siswa untuk menemukan atau mengaplikasikan ide-ide mereka sendiri, di samping mengajarkan siswa untuk menyadari dan sadar akan strategi belajar mereka sendiri. Berpijak pada uraian latar belakang di atas, maka perlu kiranya diadakan suatu tindakan melalui penelitian pendidikan. Dalam hal ini, peneliti mengangkat satu topik yang sesuai dengan kondisi yang dihadapi saat ini, yaitu: "peningkatan prestasi belajar PKn materi globalisasi dengan metode index card match pada siswa kelas IV SDN 1 Kedungsigit Kecamatan Karangan Semester II Tahun Pelajaran 2014/2015.

\section{METODE}

Penelitian yang dilakukan ini adalah Penelitian Tindakan kelas (PTK) atau Classroom Action Research. Penelitian ini merupakan penelitian tindakan di mana sesuai dengan namanya penelitian dilakukan disertai dengan berbagai macam tindakan sesuai dengan yang dibutuhkan. Inilah yang membedakan antara penelitian tindakan kelas dengan model penelitian lainnya. Penelitian Tindakan Kelas (PTK) adalah suatu pencermatan terhadap kegiatan belajar berupa suatu tindakan, yang sengaja dimunculkan dan terjadi dalam suatu kelas secara bersama (Arikunto, 2011:3).

\section{Rancangan Penelitian}

Metode yang digunakan dalam penelitian ini adalah Penelitian Tindakan Kelas (PTK). Penelitian Tindakan Kelas merupakan suatu penelitian tindakan dalam bidang pendidikan yang bertujuan untuk memperbaiki atau meningkatkan mutu pembelajaran di kelas. Penelitian Tindakan Kelas yaitu suatu bentuk penelitian yang bersifat reflektif dengan melakukan tindakan-tindakan tertentu agar dapat memperbaiki atau meningkatkan praktek-praktek pembelajaran di kelas secara lebih propesional. Penelitian tindakan kelas (Classroom Action Research) mengacu apa yang dilakukan guru dalam kelas untuk melihat kembali, mengkaji secara seksama dan menyempurnakan kegiatan pembelajaran yang telah dilaksanakan serta memperbaiki proses pembelajaran yang kurang atau dirasakan kekurangan agar menjadi lebih berhasil atau efektif, efisien, dan menarik. Penelitian yang dilaksanakan ini menggunakan Penelitian Tindakan Kelas (PTK) Sesuai dengan jenis penelitian yang dipilih, yaitu penelitian tindakan, maka penelitian ini menggunakan model penelitian tindakan dari Kemmis dan Taggart (Sugiarti, 1997:6), yaitu berbentuk spiral dari sklus yang satu ke siklus yang berikutnya. Setiap siklus meliputi planning (rencana), action (tindakan), observation (pengamatan), dan reflection (refleksi). Langkah pada siklus berikutnya adalah perncanaan yang sudah direvisi, tindakan, pengamatan, dan refleksi. Sebelum masuk pada siklus 1 dilakukan tindakan pendahuluan yang berupa identifikasi permasalahan. Perbaikan pembelajaran dilaksanakan melalui proses pengkajian berdaur, yang terdiri dari empat tahap yaitu perencanaan (planning), pelaksanaan (action), mengamati (observation), dan refleksi (reflection).

\section{Perencanaan}

Tahap ini adalah tahap pertama dalam penelitian. Tentunya segala sesuatu pasti didahului dengan adanya perencanaan. Ada beberapa aktifitas yang dapat dilakukan pada tahap perencanaan sebagai berikut mengidentifikasi masalah yang 
terjadi pada proses pembelajaran, merencanakan pembelajaran sesuai dengan hasil refleksi, mengembangkan skenario pembelajaran dalam bentuk RPP, menyusun LKS sesuai dengan materi, menyiapkan sumber dan media pembelajaran, menyusun soal evaluasi, dan menyusun format pengamatan.

\section{Pelaksanaan}

Hal yang dilakukan adalah apa yang tertuang pada tahap perencanaan, dan sesuai dengan model pembelajaran yang langkah pelaksanaan tindakan dengan model pembelajaran metode index card match meningkatan prestasi belajar PKn.

\section{Pengamatan}

Selama pembelajaran berlangsung, tidak hanya menanamkan konsep kepada siswa. Tetapi lebih jauh dari itu, melakukan pengamatan. Hal-hal yang diamati adalah tentang aktifitas siswa selama kegiatan pembelajaran khususnya pada saat kegiatan inti berlangsung. Pedoman yang dipergunakan adalah lembar pengamatan, memberi tanda check list $(\sqrt{ })$.

\section{Refleksi}

Tahapan ini merupakan kegiatan mengevaluasi dan meninjau kenmali pelaksanaan pembelajaran dan hasil observasi yang dilakukan sebagai bahan pertimbangan untuk melakukan perbaikan sebagai tindak lanjut. Tahap merefleksi untuk mencari beberapa masukan dari proses pembelajaran yang baru saja dilakukan, menemukan hal-hal yang dianggap agak fatal dalam melaksanakan kegiatan pembelajaran, yang untuk selanjutnya dapat dicarikan jalan keluarnya.

\section{Teknik Pengumpulan Data}

Peneliti mempergunakan teknik atau metode pengumpulan data sesuai dengan data yang diperlukan. Data yang diperlukan adalah data tentang prestasi belajar, masing-masing siklus peneliti mempergunakan teknik pengumpulan data tes. Tes yang dipergunakan adalah tes akhir. Data lain yang diperlukan adalah data tentang keaktifan siswa. Penelitian ini digunakan pula tes sebagai teknik pengumpul datanya. Tes yang digunakan adalah tes yang mengukur kemampuan aspek kognitif siswa, yang terdiri dari 10 soal tes pilihan ganda. Dari hasil pengambilan data baik data proses belajar mengajar, tes formatif dan data keterkaitan kemudian dianalisis untuk mencari alternatif pemecahan pada perbaikan pembelajaran berikutnya.

\section{Teknik Analisa Data}

Analisis dari data yang telah diperoleh adalah dengan menggunakan teknik analisis data statistik. Dalam penelitian ini, analisis data dimulai sejak awal sampai akhir pengumpulan data. Data yang diperoleh dari perhitungan persentasi dari hasil penilaian observasi pada saat tindakan dilakukan. Hasil observasi tersebut kemudian dianalisis terhadap indikator penggunaan peningkatan prestasi belajar bahasa Indonesia dengan menggunakan penggunaan media gambar Analisis data adalah data dari seluruh responden atau sumber data lain terkumpul. Analisis data dilaksanakan secara kualitatif dan kuantitatif pada setiap akhir siklus pembelajaran serta data hasil belajar siswa, data yang dianalisis meliputi data hasil observasi kegiatan guru dan aktifitas siswa.

\section{HASIL}

Dari hasil pengamatan peneliti, siswa belum pernah diajarkan untuk berpikir kritis dan mayoritas siswa masih rendah kemampuan pemecahan masalah. Keterampilan diskusi perlu ditanamkan sejak dini karena merupakan dasar yang diperlukan untuk memahami masalah-masalah PKn yang begitu banyak dan tidak mungkin dipelajari secara keseluruhan di kelas, maka sangat diperlukan 
membekali siswa dengan hal ini. Mereka tidak menguraikan tahapan pemecahan masalah seperti memahami masalah, membuat rencana penyelesaian, melaksanakan penyelesaian dan mengecek kembali hasil penyelesaian. Hal ini disebabkan siswa belum terbiasa menyelesaikan soal sebagaimana halnya peneliti harapkan. Menindaklanjuti pembelajaran dengan hasil tes siswa yang masih rendah, menyebabkan peneliti membuat rencana tindakan. Pelaksanaan tindakan kelas disesuaikan dengan rencana pembelajaran yang telah dirumuskan sebelumnya. Berdasarkan hasil analisis dan diskusi dengan observer, maka kegiatan proses pembelajaran dinyatakan tuntas, kepada para siswa diberikan motivasi untuk penguatan pada materi pembelajaran berikutnya.

\section{PEMBAHASAN}

Ketuntasan belajar pra siklus mencapai angka $10 \%$ atau 1 orang siswa, sedangkan nilai rata-rata secara klasikal hanya 56,00. Kenyataan hasil pembelajaran menunjukkan adanya permasalahan pembelajaran yang memerlukan penanganan khusus yang akan dilakukan dengan melaksanakan kegiatan penelitian tindakan kelas. Pada siklus 1 rekapitulasi nilai tes nilai rata-rata prestasi belajar pada pelaksanaan perbaikan pembelajaran siklus pertama sebesar 66,00. Jumlah siswa yang tuntas belajarnya sebanyak 6 siswa atau sebesar $60 \%$. Jumlah siswa yang belum tuntas belajarnya sebanyak 4 siswa atau sebesar $40 \%$. Dapat disimpulkan bahwa hasil nilai tes mengalami peningkatan dari kondisi awal, namun belum memenuhi kriteria keberhasilan yang ditetapkan yaitu minimal siswa tuntas $85 \%$ dari jumlah seluruh siswa dan nilai rata-rata hasil belajar minimal 70 . Rekapitulasi nilai siklus II nilai ratarata prestasi belajar pada pelaksanaan pembelajaran sebesar 74,00. Jumlah siswa yang tuntas belajarnya sebanyak 10 siswa atau sebesar $100 \%$, dan tidak ada siswa yang belum tuntas belajarnya atau sebesar $0 \%$. Dapat disimpulkan bahwa hasil nilai tes mengalami peningkatan dari siklus I, karena pada siklus II semua siswa dinyatakan tuntas belajarnya, sehingga dapat disimpulkan bahwa kriteria keberhasilan pelaksanaan penelitian tindakan kelas telah tercapai.

Berdasarkan hasil pengolahan data-data dan hasil observasi dilakukan analisis dan dapat diketahui bahwa semua tujuan telah tercapai sesuai dengan kriteria yang ditentukan. Terkaji bahwa pembelajaran berlangsung sangat kondusif dan interaktif. Siswa tampak senang belajar. Hal ini tampak dari kesungguhan siswa dalam pelaksanaan kegiatan diskusi kelompok yang dilanjutkan dengan diskusi kelas. Siswa nampak antusias dan bersemangat dalam pelaksanaan kegiatan diskusi kelas, hal ini dibuktikan dengan peningkatan motivasi yang siswa sangat baik. Siswa memiliki sikap disiplin waktu, sehingga mampu menjadikan siswa memanfaatkan waktu yang tersedia dengan sebaik-baiknya. Motivasi belajar siswa sangat tinggi, diketahui dari frekwensi yang muncul pada saat guru memberi kesempatan siswa untuk mengerjakan soal di depan kelas sehingga prestasi belajarpun dapat meningkat dengan baik.

Berdasarkan data-data hasil pelaksanaan pembelajaran sebagaimana diuraikan di atas berupa data hasil tes siklus I, tes siklus II dan data hasil observasi siklus I dan II maka dapat disimpulkan bahwa penggunaan metode index card match dapat meningkatkan prestasi belajar siswa.

\section{KESIMPULAN}

Berdasarkan analisis data dan hasil temuan, dapat peneliti tarik kesimpulan antara lain, sebagai pembelajaran metode index card match dapat meningkatkan prestasi belajar yang ditunjukkan dengan peningkatan nilai rata-rata prestasi belajar yang terus meningkat. Peningkatan nilai hasil dan ketuntasan belajar siswa dapat disimpulkan pada temuan awal siswa yang tuntas sebanyak 1 siswa atau $10 \%$ dari 10 siswa. Pada siklus I siswa yang tuntas sebanyak 6 siswa atau $60 \%$ dari 10 siswa. Pada siklus II siswa yang tuntas sebanyak 10 siswa atau $100 \%$ dari 10 siswa. Dan siswa belum tuntas pada temuan awal siswa yang belum tuntas sebanyak 9 siswa atau $90 \%$ dari 10 siswa. Pada siklus I siswa yang belum tuntas sebanyak 4 siswa atau $40 \%$ 
dari 10 siswa. Selanjutnya pada siklus II siswa yang belum tuntas sebanyak 0 siswa atau $0 \%$ dari 14 siswa. Peningkatan nilai rata-rata prestasi belajar pada pembelajaran PKn tema globalisasi dengan menggunakan metode index card match menunjukkan peningkatan yang cukup signifikan di mana pada kondisi awal sebesar 56,00 meningkat menjadi 66,00 pada siklus I dan pada akhir siklus II meningkat menjadi 74,00 .

\section{SARAN}

Keberhasilan penelitian tidak hanya terfokus pada pengaruh model pernbelajaran tetapi juga berpengaruh dari komponen pembelajaran yang lain, maka dalam penelitian-penelitian selanjutnya hendaknya dicantumkan pula komponen pembelajaran lain baik metode, sarana, ataupun alat bantu belajar dan lain-lainnya. Metode index card match terbukti telah meberikan manfaat yang besar dalam memperbaiki proses maupun hasil belajar siswa dalam pembelajaran. Atas dasar itu, sudah selayaknya metode ini diterapkan secara sungguh-sungguh dalam proses pembelajaran PKn, baik pada materi globalisasi maupun pada materi-materi pembelajaran yang lain.

\section{DAFTAR RUJUKAN}

Alatas, Husein. 1982. Berbagai Jenis Peta dan Kegunaannya. Yogyakarta: Liberty Arikunto, Suharsimi. 2011. Penelitian Tindakan Kelas. Jakarta: BumiAksara Baharuddin. 2008. Teori Belajar dan Pembelajaran. Ar-Ruzz Media: Yogyakarta Bahri, Siaful, dkk. 1994. Strategi Belajar Mengajar. Jakarta: Rineka Cipta.

Dahlan. 1994. Kamus Bahasa Indonesia Pupoler. Surabaya: Arkola

Depdiknas. 2003. Undang-Undang SISDIKNAS 2003, Fokusmedia Bandung

Depdiknas. 2005. Peraturan Pemerintah RI No. 19 Tahun 2005 tentang Standar Peniliaian Pendidikan. Jakarta.

Hamalitik, oemar. 1981. Media Pendidikan. Bandung: PT Citra Aditya Bakti.

Imran, Ali. 1987. Belajar dan Pembelajaran. Jakarta: PT Dunia Pustaka. Jaya.

Laily. 2002. Strategi Pembelajaran Agama Islam Berbasis PAIKEM, (Semarang: Rasail Media Group, 2008

Rahmat, dkk. 2009. Pembelajaran Pendidikan PKn. Bandung: Laboratorium Pendidikan Kewarganegaraan. UPI.

Syaifudi. 2003. Strategi Pembelajaran Aktif, Yogjakarta: Pustaka Insan Madani Syaiful Bahri. 1994. Psikologi Belajar $2^{n^{d}}$. ed. Jakarta: PT. Rineka

Suryabrata, Sumadi. 1998. Psikologi Pendidikan. Jakarta: Raja Grafindo Persada.

Suryabrata, Sumadi. 2002. Psikologi Pendidikan. Jakarta: Raja Grafindo Persada.

Surakhmad, Winarno. 1986. Strategi Belajar Mengajar. Bandung: CV Sinar Baru.

Winkel, W.S. 1989. Psikologi Pengajaran. Jakarta: PT. Gramedia.

Winataputra, US, dkk. 2001. Strategi Belajar Mengajar. Jakarta: Universitas Terbuka. 